\section{Current situation with doctors and healthcare workers during COVID-19 pandemic in India}

The WHO formally declared the novel coronavirus severe acute respiratory syndrome coronavirus 2 (SARS-CoV-2) outbreak a pandemic on 11 March 2020 with the publication of public health guidelines to guide the pandemic response. ${ }^{1}$ Serious illness may need hospitalisation and ventilatory support. ${ }^{2}$ To reduce the risk of person-to-person viral transmission during the COVID-19 pandemic, the Indian government introduced various measures including 'lockdown' on 23 March 2020 with 'social distancing' and 'self-isolation' strategies and recommended shielding of at-risk individuals. ${ }^{3}$ The lockdown measures reduced the movement of individuals and consequently has had a significant impact of daily life of Indian people with disruption of economic, social and access to healthcare facilities. ${ }^{45}$ This has made people fearful, anxious, and sometimes they have found it difficult to access emergency treatment. ${ }^{45}$ India has a combination of government and private healthcare facilities for providing medical care. Due to fear and to avoid the risk of spreading the novel coronavirus SARS-CoV-2 infection, many hospitals have closed their doors to patients who have been trying to avail these facilities. This has led to restlessness, irritation and sometimes despair when trying to find medical help. As a consequence of this, people have shown their frustration by verbally abusing and threatening to physically assault doctors and other healthcare workers.

\section{CURRENT SITUATION}

Doctors and healthcare workers who are responding to a global health crisis-trying to protect individuals, families and communities in adverse situations with stretched resources, shortage of personal protective equipment (PPE) and other equipment's-have found themselves as unexpected targets in the fight against COVID-19. ${ }^{6}$ There have been several reported incidences of such violence against them during this pandemic time in India. Although the exact numbers of such cases cannot be determined, there are a few glaring examples: on 8 April 2020, two trainee doctors in New Delhi were allegedly assaulted by a neighbour who accused them of spreading the disease. On19 April 2020, the burial of a neurosurgeon who had died after contracting COVID-19 in Chennai was disrupted by a mob who attacked the undertakers. The citizens' opposition was due to a misconception that the contagion may spread in the neighbourhood if the surgeon was buried there. ${ }^{7}$ A group of public health workers in Indore, a city in central India, who were trying to 'contacttrace' a person, were descended upon by a group of 100 people pelting stones and drove them away. Increasingly, reports pour in of doctors being spat on, hurled abuses at and driven away.

\section{CHALLENGES FACED BY THE DOCTORS AND HEALTHCARE WORKERS}

The violence against doctors and other medical personnel has increased over the past few decades, with up to $75 \%$ doctors facing this during their practice in India. ${ }^{8}$ Doctors attribute the surge in violence against healthcare workers to a mix of ignorance and fear, which is amplified by the pandemic. ${ }^{9}$ The lockdown has exacerbated the problem, with patients unable to access healthcare due to transport suspension, fear of law enforcement and frustration following quarantine or containment zone restrictions. The types of attacks have ranged from verbal abuse, verbal threats or aggressive gestures in majority of cases. ${ }^{10}$ However, there have also been serious reports of manhandling, abduction and murder. ${ }^{8}$

The reasons for violence against healthcare workers may vary from fear, anxiety, panic, misinformation (as to how the SARS CoV-2 virus outbreak may spread and affect individuals), mistrust and misplaced quotes in the social-media. ${ }^{11}$ Government hospitals in India are inundated in such public health crisis with lack of adequate facilities, equipment and infrastructure are other quoted reasons. The private hospital sectors have largely shut down to nonemergency admissions, and people find it difficult to access medical aid. Aggressive emotional response of relatives may sometimes boil over with frustration exhibited in the form of damage to the healthcare facilities and verbal or physical violence against the healthcare personnel. The situation is being made more difficult as health units and professionals in some government hospitals highlight shortage of PPE but do receive hostile response from hostile hospital administration. ${ }^{9}$ Health professionals are recognised as 'newer untouchables'. People are panicked about catching COVID-19 from medical workers or being stigmatised for having contracted it themselves. ${ }^{12}$

\section{STRATEGIES TO COMBAT VIOLENCE}

\section{Better communication}

A better and timely communication with the aggrieved patients and their family members is the key to avoid violence and untoward incidences. ${ }^{13}$ Due to shortage of time and to maintain social distancing norms, often the verbal and direct communication between doctors and patients is lacking during this pandemic. It leaves the patient and the family 'in the dark' and unsatisfied. The hospitals should designate some social workers and counsellors to coordinate with them on a regular basis to allay any fears.

\section{Role of media}

Social media including both the printed and the digital media has a significant role in the spread of information in India and are known to sensationalise stories about medical negligence and malpractice. ${ }^{8}$ The widespread news coverage about COVID-19 has heightened anxiety and fear among the Indian public. Social media platforms can play a positive role in the current pandemic collaborating with Government agencies to provide an effective information campaign to educate the public about the diagnosis, spread, containment and prevention strategies against COVID-19 transmission. The uptake of 'Aarogya Setu'-Indian government's COVID-19 contact tracing application-can be promoted by smart phone technology companies and web providers to minimise the spread of COVID-19, thus help to safely reduce lockdown measures. ${ }^{14}$ This will help prevent a 'second wave' of viral outbreak in the future.

\section{Self-defence}

Violence against doctors is underreported in India, perhaps because the doctors fear for their personal safety and harassment from public, administration and law enforcement system. Recently, doctors and government institutions have started to take steps to protect themselves against violence. Marshalls have been posted at large central government hospitals in Delhi in their accident and emergency department. ${ }^{15}$ The All India Institute of Medical Sciences, New Delhi, has started self-defence training among doctors for protection. ${ }^{16}$ At places, doctors have had to evaluate patients from a distance to avoid assault and this hampers history taking and examination of the patient properly. 


\section{Government strategy}

Concerned with the rising violence against the doctors and healthcare workers, the Indian government has recently issued an ordinance that makes violence against healthcare workers a nonbailable offence, punishable by up to 7 years imprisonment. ${ }^{9}$ The Ordinance-an amendment of India's age-old Epidemic Diseases Act 1897- seeks to protect doctors, nurses, and paramedic and community health workers from harassment or physical injury, which has been introduced following an upsurge of violence against healthcare workers since the start of COVID-19 pandemic. It has been welcomed by all quarters to rein in violence and punish the wrongdoers. It is expected to be a deterrent, if applied and executed strictly. However, currently, it is an amendment of the epidemic act and it is unclear how the regulation will be applied once the pandemic has resolved. Recently, to give support and respect to emergency workers like doctors and paramedics during the COVID-19 pandemic, the government has urged people to clap or ring any musical instrument on a designated day and time. This has improved the respect of healthcare workers and corona warriors to some extent.

\section{Role of telemedicine}

Telehealth has been a game changer and one of the positives that has emerged out of this COVID-19 pandemic and will be an integral part of healthcare in the post-COVID-19 era. Use of telehealth will reduce the face-toface contact of patient and thus may reduce the physical assault to the doctors to some extent. The thought of recording of the telemedicine services may force the patients and their caregivers to behave properly and thus prevent verbal abuse and threats.

\section{Role of education and better primary healthcare}

Education of the masses and better access to primary healthcare services is vital to reduce violence against doctors and healthcare workers. Time has to identify effective ways and means to improve and strengthen public health education and practice. This is necessary not only to educate the population about the importance of prevention of infection, hand hygiene in preventing communicable diseases prevalent in India but also the importance of various healthcare workers in delivering healthcare programmes. Doctors and healthcare workers need to be supported in carrying out their fight against global health crisis such as COVID-19 pandemic, understand their limitations due to lack of resources and thus minimise incidents of violence. Establishment of better primary healthcare facilities such as Delhi's Mohalla (community) and Mumbai's Swasth (health) clinics is one of the right ways forward to access local healthcare. ${ }^{17}$

\section{CONCLUSION}

COVID-19 health crisis has exacerbated violence against doctors and healthcare workers. They have become unforeseen targets in the fight against the current pandemic. For a sustainable protection of the healthcare workers, the current Ordinance needs to be further extended and incorporated into existing laws in the form of a strict, permanent legislation that is strictly enforced. It would improve the safety of the very individuals who carry out their duties fearlessly for the benefit of sick patients, either during a health crisis such as the current pandemic or during traditional times.

\section{Karthikeyan P Iyengar, ${ }^{1}$ Vijay Kumar Jain (iD) ${ }^{2}$} Raju Vaishya ${ }^{3}$

${ }^{1}$ Trauma and Orthopaedics, Southport and Ormskirk NHS Trust, Southport, UK

${ }^{2}$ Orthopaedics, Atal Bihari Vajpayee Institute of Medical Sciences, Dr. Ram Manohar Lohia Hospital, New Delhi, India

${ }^{3}$ Orthopaedics, Indraprastha Apollo Hospital, New Delhi, India

Correspondence to Vijay Kumar Jain, Department of Orthopaedics, Atal Bihari Vajpayee Institute of Medical Sciences, Dr. Ram Manohar Lohia Hospital, New Delhi 110001, India; drvijayortho@gmail.com

Contributors $\mathrm{KPI}$ involved in writing the original draft of manuscript, literature search, planning, conduct and editing. VKJ and RV involved in conceptualisation, literature search, review and editing. $\mathrm{KPI}, \mathrm{VKJ}$ and RV approved the final draft.

Funding The authors have not declared a specific grant for this research from any funding agency in the public, commercial or not-for-profit sectors.

Competing interests None declared.

Patient consent for publication Not required.

Provenance and peer review Not commissioned; externally peer reviewed.

This article is made freely available for use in accordance with BMJ's website terms and conditions for the duration of the COVID-19 pandemic or until otherwise determined by BMJ. You may use, download and print the article for any lawful, noncommercial purpose (including text and data mining) provided that all copyright notices and trade marks are retained.

(C) Author(s) (or their employer(s)) 2020. No commercial re-use. See rights and permissions. Published by BMJ.

\section{A) Check for updates}

To cite lyengar KP, Jain VK, Vaishya R. Postgrad Med J 2020:0:1-2.
Accepted 11 July 2020

Postgrad Med J 2020;0:1-2.

doi:10.1136/postgradmedj-2020-138496

ORCID iD

Vijay Kumar Jain http://orcid.org/0000-0003-41647380

\section{REFERENCES}

1 World Health Organization. Coronavirus disease (COVID-19) advice for the public. 2020. Available https://www.who.int/emergencies/diseases/novelcoronavirus-2019/advice-for-public (accessed 30 May 2020)

2 Yang $X, Y u Y, X u J$, et al. Clinical course and outcomes of critically ill patients with SARS-CoV-2 pneumonia in Wuhan, China: a single-centered, retrospective, observational study. Lancet Respir Med 2020:8:475-81.

3 COVID-19 India. Available https://www.mohfw.gov.in (accessed 30 May 2020)

4 Lancet T. India under COVID-19 lockdown. Lancet 2020;395:1315.

5 Haleem A, Javaid M, Vaishya R, et al. Effects of COVID-19 pandemic in the field of orthopaedics. J Clin Orthop Trauma 2020;11:498-9.

6 Health workers become unexpected targets during covid-19. Editorial. Economist. Available https://www. economist.com/international/2020/05/11/healthworkers-become-unexpected-targets-during-covid-19 (accessed 11 May 2020)

7 Violence mars COVID-19 doctor-victim's burial editorial. Times of India. Available http:// timesofindia.indiatimes.com/articleshow/75255847. cms?utm_source=contentofinterest\&utm_medium = text\&utm_campaign=cppst (accessed 19 Apr 2020)

8 Kapoor MC. Violence against the medical profession. I Anaesthesiol Clin Pharmacol 2017;33:145-147.

9 News Editorial, BMJ. COVID-19: Indian government vows to protect health care workers from violence amid rising cases. BMJ 2020;369.

10 Ghosh K. Violence against doctors: a wake-up call. Indian J Med Res 2018;148:130-133.

11 McKay D, Heisler M, Mishori R, et al. Attacks against health-care personnel must stop, especially as the world fights COVID-19 [published online ahead of print, 2020 May 20]. Lancet 2020.

12 Altstedter A, Shrivastava B, Pandya D. Doctors, hospital workers are also fighting abuse and violence as virus stigma, panic grows. Available https://theprint.in/india/ doctors-hospital-workers-are-also-fighting-abuse-andviolence-as-virus-stigma-panic-grows/401144/

13 Vaishya R, Maini L, Vaish A. Making the surgeons safe in India. Indian J Orthop 2018;52:212-213.

14 Ministry of Health and Family Welfare, Government of India. Aarogya Setu. Available https://www.mygov.in/ aarogya-setu-app/

15 Appoint marshalls in hospitals for doctor's security editorial. Available https://www.latestlaws.com/latest-news lappoint-marshalls-in-hospitals-for-doctors-security/ (accessed 9 Jul 2019)

16 Jha D. AllMS doctors to get self-defence training. Available https://timesofindia.indiatimes.com/city/ delhi/aiims-doctors-to-get-self-defence -training/articleshow/58487081.cms (accessed 3 May 2017)

17 Hegde A. Violence in hospitals: three steps towards mending doctor-patient relationships. Available https://scroll.in/pulse/837572/violencein-hospitals-three-steps-towards-mendingdoctor-patient-relationships (accessed 15 May 2017) 